\title{
A Study on Guided Peer Feedback in Group Work to Improve Non-English-Majored Graduates' English Writing in Internet-Based Language Laboratory
}

\author{
Yougen Lou*, Zejuan Li, Ping Gong, Jianjun Liu* \\ School of Foreign Studies, Yangtze University, Jingzhou City, China \\ Email: *louyougen@163.com
}

How to cite this paper: Lou, Y.G., Li, Z.J., Gong, P. and Liu, J.J. (2016) A Study on Guided Peer Feedback in Group Work to Improve Non-English-Majored Graduates' English Writing in Internet-Based Language Laboratory. Open Journal of Social Sciences, 4, 86-96.

http://dx.doi.org/10.4236/jss.2016.410007

Received: September 23, 2016

Accepted: October 18, 2016

Published: October 21, 2016

Copyright $\odot 2016$ by authors and Scientific Research Publishing Inc. This work is licensed under the Creative Commons Attribution International License (CC BY 4.0).

http://creativecommons.org/licenses/by/4.0/ (c) (1) Open Access

\begin{abstract}
Peer feedback is a key to the quality of group work in foreign language classrooms. In order to better understand the use of peer feedback in writing, a fifteen-week study was conducted by combining peer feedback in group work with the internet-based language laboratory (IBLL). 80 non-English-majored graduates from Yangtze University participated in this study. 40 non-English-majored graduates in EG were randomly divided into 10 groups and one group member from every group was chosen as the leader in a group. Based on Scaffolding Instruction of Constructivism, this study chose three different tools-a checklist, a qualitative feedback sheet and a grading sheet, to guide peer feedback. Two tests and questionnaires were adopted to investigate the students' views and attitude toward guided peer feedback in IBLL. We found: 1) the method of peer feedback in group work with support of IBLL could improve non-English-majored graduates' writing ability; 2) there were significant differences between males in CG and EG, and females in CG and EG; 3) students in EG held the positive response for the combined writing instruction through the data of questionnaires.
\end{abstract}

\section{Keywords}

Guided Peer Feedback, Group Work, English Writing, Internet-Based Language Laboratory

\section{Introduction}

Writing ability is important for non-English-majored graduates in writing academic papers to express their academic ideas to readers. However, it is difficult for Chinese 
non-English-majored graduates to write the academic papers in English to express their academic ideas to foreign readers. To improve Chinese non-English-majored graduates' writing ability is an important subject for studying. Suggestions and new ideas from peers with support of the internet-based language laboratory (IBLL) would improve non-English-majored graduates' writing skills even writing ability. In the framework of the task-based language learning, group work is regarded as a chief organizational form of learning [1], because it enhance interaction and negotiation of meaning which can lead to language acquisition. However, the quality of group work varies widely in practice, and research into the means of group work enhancement is required urgently.

Peer feedback is a key to the interaction and language learning in groups. Rollinson [2] explains, "In recent years, the use of peer feedback in ESL writing classrooms has been generally supported in the literature as a potentially valuable aid for its social, cognitive, affective, and methodological benefits". In fact, there are a lot of advantages of peer feedback for students in writing. First of all, peer feedback is suggested as pedagogy of providing more self-control to language learners [3]. In additional, replying to peer corrections and giving suggestions allow students to see similar problems and weaknesses in their own writing [4]. The present work focuses on the means of guidance in initiating effective peer feedback in group work for non-English-majored graduates' writing with support of IBLL.

\section{Literature Review}

\subsection{The Role of Peer Feedback in Group Work}

\subsubsection{Definition of Peer Feedback}

Peer feedback can be defined as "the use of learners as sources of information and interactants for each other in such a way that learners assume roles and responsibilities normally taken on by a formally trained teacher, tutor, or editor in commenting on and critiquing each other's drafts in both written and oral formats in the process of writing" [5]. Peer feedback is also regarded as a process in which students evaluate each other's work among themselves [6].

\subsubsection{Functions of Peer Feedback in Group Work}

Peer feedback can raise learners' awareness of their strong points and weak points, increase a sense of audience, encourage cooperative learning, and foster ownership [7]. According to Van den Berg, Admiraal, and Pilot [8] small group work is beneficial for learning based on peer feedback if organized well. Many benefits of peer feedback have been claimed: providing an authentic audience to students; increasing student motivation for speaking; enabling students to get different viewpoints; helping students learn to listen critically; helping students gain confidence in their speaking and encouraging students to use oral language skills [9]; and also helping students learn to evaluate their own speaking better.

\subsection{Implementation of Peer Feedback in Group Work}

Yang, Richard and $\mathrm{Yu}$ [10] identify two main issues as a prerequisite for successful use 
of peer feedback when implementing it: the size of peer feedback group and the form of training. In peer feedback research, the size of groups varies, while pairs and groups of three and four are mainly adopted. Groups of three or four were used in some studies [11] [12] and it was found that group dynamics could strongly affect peer feedback groups' functioning. Especially in large classes, groups of three or four could help increasing class interaction.

Approaches to training students on how to provide feedback are also prone to variation. The students in the study of Tsui and $\mathrm{Ng}$ [7] were only given broad categories when they needed to write comments. Zhu [12] reported that their students received training through watching a video.

\section{Methods}

\subsection{Subjects}

In September 2012, 80 first-year non-English-majored Chinese graduates from Yangtze University were volunteers in this study. Among the 80 subjects, they were 42 females and 38 males, average age 23. Their majors were horticulture, agriculture, plant protection, biological technology. All 80 subjects were taught by the same instructor during the whole academic term (September, 2012 to January, 2013). All 80 subjects who passed the College English Test Band 4 were divided randomly into two groups. One group of 40 subjects was regarded as the Control Group (CG) with the traditional graduate English writing method in IBLL, and other 40 subjects were as the Experiment Group (EG) with the method of guided peer feedback in group work with support of IBLL. Both CG and EG, their level of education, family background, age, personality and life experiences and other factors were same, that was to say, their overall learning and cognitive abilities were almost equal. 40 subjects in EG were randomly divided into 10 groups, 4 subjects per group and one student chosen as the leader in every group to organize group members to discuss the peer feedback related to their writing.

\subsection{Research Design}

The study was to investigate that 1) Compared with CG, did peer feedback in group work with support of IBLL help non-English-majored graduate students improve their English writing skills and writing ability? 2) Compared with CG, after the training of peer feedback in group work with support of IBLL, was there the significant difference on the writing scores between the two groups; 3) Was the method of peer feedback in group work beneficial to all graduate students of EG in English writing in this study? A comparative research method was used in this study.

\subsection{Peer Feedback Design}

\subsubsection{The Measures of Peer Feedback}

When organizing peer feedback, the following measures [13] were used:

1) Supplying purposeful and proper peer feedback sheets for a given task and purpose. 
This depended on whether the focus of each task was on the organization, content, or vocabulary.

2) Helping students to be familiar with peer feedback procedures.

Students were encouraged to ask questions related to peer feedback and teachers provided students some examples of peer feedback such as video.

3) Instructing students to ask proper and right questions.

Unless they were guided to ask proper questions and look for problematic issues, students may not make appropriate comments.

4) Monitoring groups and peer feedback.

The teacher took part in the activity as a peer or stayed in each group for some time to remind students of proper expressions.

\subsubsection{Instruments}

The instruments used in this study were three tools, two tests (the English writing test before the training of peer feedback in group work with support of IBLL, the English writing test after the training of peer feedback in group work with support of IBLL) and questionnaires.

Three tools: Three tools were used to assist peer feedback: checklists, grading sheets and qualitative feedback sheets. They were adopted on the basis of the following considerations.

First, they were based on Scaffolding Instruction of Constructivism. The students needed specific guidance in how to provide feedback so that they could understand what to focus on and how to make an evaluation. The three forms were chosen to achieve this purpose.

Second, these forms of peer feedback are strongly operational. For example, a quantitative feedback sheet differs from a peer feedback checklist, which depends on whether the focus of the task is on the content, organization, or vocabulary.

Third, the three tools represent different forms of guidance. The evaluation standard and what they focus on are different. Checklists focus on the content, grading sheets focus on the organization while qualitative feedback sheets focus on details.

English writing applied ability pre-test: All the 80 non-English-majored graduates were attended the English writing test (from College English Test 6 (CET 6) in June, 2011) to gain students' writing level in CG and EG before the experiment.

English writing applied ability post-test: All the 80 non-English-majored graduates were attended the English writing test (from College English Test 6 (CET 6) in June, 2012) to gain students' changes in writing between CG and EG after the experiment.

Questionnaires: The model of the questionnaire from Grace Hui Chin Lin and Paul Shih Chieh Chien [14] was adopted in this study (see Appendix). There were ten questions with levels of three different degrees: 1 for Strongly Agree, 2 for Agree, 3 for Not Agree and 4 for Strongly Disagree. Before the experiment, the questionnaire was tested, the reliability was 0.78 . The questionnaires in this study were used to collect the data on guided peer feedback in group work with support of IBLL from non-English-major graduate students. 


\subsection{Research Schemas}

The experiment for EG in this study lasted for 16 weeks and was divided into4 sessions.

1) Session 1 (the first four weeks), the power point files about writing strategies had to be introduced to the non-English-majored graduates in EG.

2) Session 2 (the second four weeks), non-English-majored graduates in EG were guided to write their draft related to the course in class and peer feedback about their drafts in group work with support of IBLL .was executed.

3) Session 3 (the third four weeks), researcher cooperators would be suggested to find a positions toward peer feedback pedagogies. At the same time, non-English majored graduates in EG learned writing strategies with their trainer and their drafts were revised by their peers to provide peer feedback in group work with support of IBLL.

4) Session 4 (the last four weeks), data through survey provided by all the 40 graduates in EG would be transcribed, analyzed and reported.

\subsection{Data Collection and Analyses}

Before the research experiment (September 2012) and after the experiment (January, 2013), two tests on English writing applied ability were conducted to compare changes between the two groups of students in English writing ability. In this study, social scientific software SPSS 15.0 was used for statistical analysis to the collected data. In order to find out the method of peer feedback in group work in English writing proved superior to the conventional teaching (such as students writing-teachers correcting) method, comparison of Means was adopted to compare two groups of non-Englishmajored graduate students' average scores of their pretest and after the experiment on the basis of samples. And the independent sample T-test was adopted to exanimate if there were significances between CG and EG before the experiment and after the experiment. Data of questionnaires for 20 volunteers out of the 40 subjects in EG were analyzed.

\section{Results}

The results in this study included three parts. The first part was writing test results of pre-test and post-test between the control group (CG) and the experiment group (EG). The second part was that whether there were significant differences between males and females, as a teacher-dominated approach with CG was compared with peer feedback in group work in writing class of EG. The last part was that responses to the questionnaire on the peer feedback in group work in writing class were from subjects in EG

\subsection{Peer Feedback in Group Work and Writing}

From Table 1, the results showed writing tests' (CET 6) scores between CG and EG taught by different writing methods in the pre-and post-tests. In the pre-tests, no significant difference $(\mathrm{P}=0.359)$ was found between $C G(\mathrm{M}=112.85, \mathrm{~S}=12.41)$ and $\mathrm{EG}$ $(\mathrm{M}=79.18, \mathrm{~S}=8.13)$ in their writing tests. However, in the post-tests, there was a significant difference between CG $(M=80.80, S=9.31)$ and $E G(M=86.13, S=-9.270)$ in 
the writing test, $\mathrm{P}=0.005$. After the training of peer feedback in group work in an EFL writing class, the writing scores of subjects in $E G(M=120.88, S=13.52)$ were improved than that of subjects in CG $(M=116.18, S=13.01)$.

\subsection{Results of the T-Test about Males and Females in CG and EG}

From Table 2, we could see that significant differences were found between males and females in the two groups: $C G$ and EG. Males $(P=0.04)$ suggested that there was the significant difference between CG and EG in their writing ability after the training of peer feedback in group work in an EFL writing class, and females $(P=0.03)$ suggested that there was the significant difference between CG and EG in their writing ability after the training of peer feedback in group work in an EFL writing class.

\subsection{Results of the Questionnaires of Instructing Writing through Peer Feedback in Group Work with Support in Writing Class from Non-English-Major Graduates in EG}

The questionnaires from non-English-majored graduates in EG on the instruction method of peer feedback in group work with support of IBLL in class was administered to 20 volunteers out of the 40 subjects in EG at the end of the semester (January, 2013) to gain their responses for this integrated teaching method and to identify the possible benefits and problems of this method.

For Question 1, only 5 (25\%) volunteers still needed the teacher's correcting their essays and other $15(75 \%)$ volunteers agreed that their peers also could review and correct their essays as good as the writing teacher if they could discuss peer feedbacks and corrections in group work with support of IBLL in learning writing.

For Question 3, all the 20 volunteers agreed that they preferred peer feedback to teacher's feedback.

For Question 4, only 2 (10\%) volunteers strongly agreed that they could learn more from peers than that of the trainer. Only $4(20 \%)$ volunteers agreed that they could learn more from peers than the trainer. $14(70 \%)$ volunteers thought that they could learn more from the trainer than the peers.

Table 1. Results of the peer feedback in group work on non-English-major graduates' writing scores of pre-test and post-test.

\begin{tabular}{|c|c|c|c|c|c|c|}
\hline \multirow[b]{2}{*}{ Groups } & \multicolumn{2}{|c|}{ CG $(\mathrm{N}=40)$} & \multicolumn{2}{|c|}{$\mathrm{EG}(\mathrm{N}=40)$} & \multirow{2}{*}{$\mathrm{t}$} & \multirow{2}{*}{$\mathrm{P}$} \\
\hline & M & S & M & S & & \\
\hline Pre-test & 79.18 & 8.15 & 80.80 & 9.31 & 0.929 & 0.359 \\
\hline Post-test & 78.10 & 8.86 & 86.13 & 8.16 & -9.270 & $0.000^{* *}$ \\
\hline
\end{tabular}

$\mathrm{M}$ stands for Mean; $\mathrm{S}$ stands for standard deviation; ${ }^{\star} \mathrm{P}<0.05 ;{ }^{\star \star} \mathrm{P}<0.01$.

Table 2. Results of the t-test about males and females in CG and EG.

\begin{tabular}{|c|c|c|}
\hline Gender $\quad$ T (two-tailed) & Males & Females \\
\hline Probability & 0.04 & 0.03 \\
\hline
\end{tabular}


For Question 5, $16(80 \%)$ volunteers agreed or strongly agreed that through the combined writing activity, they felt more confident and supportive because the Process of cognitive interaction among the peers in group work was created.

For Question 6, all the 20 (100\%) volunteers felt more comfortable because they found the access from peer feedbacks and peer corrections to know their peer's writing proficiency.

For Question 7, all the $20(100 \%)$ volunteers agreed that they felt social interaction among their peers in group work through writing and peer feedbacks provided them more new ideas and motivations in writing.

For Question 8, 12 (60\%) volunteers strongly agreed that their writing skills were improved because of the peer feedback activity in their writing training; 6 (30\%) volunteers agreed that their writing skills were improved because of the peer feedback activity in their writing training. Only $2(10 \%)$ volunteers did not agree that their writing skills were improved because of the peer feedback activity in their training.

For Question 9, 16 (80\%) out of 20 volunteers agreed that they hoped their articles could be revised and proofread again by their peers.

For Question 10, 16 (80\%) out of 20 volunteers believed that this peer feedback pedagogy should be applied in English classes.

\section{Discussion}

This study wants to look for the answers to the three questions. One of the purposes in this study is to know if the writing instruction through peer feedback in group work with support of IBLL in class can improve non-English-majored graduates' writing skills and writing ability. Subjects' improvement in writing ability shows the important role of peer feedback in group work played in their writings.

Through results in Table 1, we could know that after the writing training, both writing scores in CG and EG were improved, but the writing scores in EG were higher than that in CG, it means that the combined writing method of peer feedback in group work with support of IBLL can improve non-English-majored graduates' writing skills and writing ability in EG after they were trained by the combined writing method. The results in this study agrees with the results in some research has shown that peer feedback improves learning [15]-[18] The method of peer feedback in group work with support of IBLL encourages students to discuss, analyze and correct their essays from new ideas and good suggestion for improving their drafts from peers, and their writing ability can be improved by the training of peer feedbacks in group work and revision methods for essays applied in revising their essays. Linn [19] writes, "Encouraging students to analyze and build on ideas from peers can introduce new perspectives and motivate students to reconsider their own ideas".

After instruction and training by the model of peer feedback in group work with support of IBLL, male and female non-English-major graduate students in EG successfully learn to provide the proper feedbacks for their peers' essays and revise their essays according to peer feedbacks about their essays, they show better in writing ability, 
compared with male and female non-English-major graduates in CG. And there are significant differences between Males and Females in CG and EG. The results could be explained by the research, for example, Hovardas et al. [20] cite research suggesting that "sharing a frame of understanding" about a problem with one's peers might make peer suggestions more accessible and more readily actionable than suggestions from a teacher [21] [22]. Male and female non-English-major graduate students in EG could have the opportunity to discuss the problems in their essay, which would provide chances for them to improve their writing ability.

Non-English-major graduates in EG generally holding positive response for the peer feedback in group work with support of IBLL training program suggest that the combination of peer feedback in group work with support of IBLL into regular EFL curriculum is a worthy try. Non-English-majored graduate students need practice writing and revising more academic-style papers related to their majors, the method of peer feedback in group work with support of IBLL is practical method for them to learn how to write and how to revise their essays with the help of peer feedback in group work with support of IBLL in class and apply the writing skills and revising skills they learned into practicing writing essays and academic-style papers. Although subjects in EG could learn the peer feedback in group work with support of IBLL, they also need the guidance from teaches. A teacher in the writing class could guide or organize the students in class and provide the guidance for students such as having difficulties in providing peer feedbacks and proper corrections in essays. It is common that some students could be shy even tense about the face-to-face peer feedbacks, which might be related to the cultural factor (most Chinese students valuing the concept of face). Some students think that students would lose their faces during face-to-face peer feedbacks if they receive the negative peer feedbacks about their essays about their essays in group work. For Chinese students, research has found that the traditional Chinese cultural issues, such as collectivism and group harmony, the concept of "face", and power distance could exert negative influence on students' engagement with or participation in peer feedback [11] [23]-[25].

\section{Limitations and Suggestions for Further Research}

This research is in small scale (only 80 subjects) and the time (only 16 weeks) does not last long. Because of the large size of a class, the researcher has difficulties in observing all the groups. Future investigation should be made about the bigger scale and the long-term impact of peer feedback in an EFL writing class.

Guided peer feedback in group work with support of IBLL in an EFL writing class applied in first-year non-English-majored graduate students can improve their English writing ability, but Guided peer feedback in group work with support of IBLL in an EFL writing class also works for other subjects such as high school students, we need further research.

We need further research on how to train students experience peer editing firsthand in order to become proficient reviewers and assist their peers in creating a better final 
product, defined as one that contained fewer grammatical and organizational errors and whose ideas were clear to the reader [26].

\section{References}

[1] Ellis, R. (1994) The Study of Second Language Acquisition. Shanghai Foreign Language Education Press, Shanghai.

[2] Rollinson, P. (2005) Using Peer Feedback in the ESL Writing Class. ELT Journal, 59, 23-30. http://dx.doi.org/10.1093/elt/cci003

[3] Mendonça C.O. and Johnson, K.E. (1994) Peer Review Negotiations: Revision Activities in ESL Writing Instruction. TESOL Quarterly, 28, 745-769. http://dx.doi.org/10.2307/3587558

[4] Grabe, W. and Kaplan, R.B. (1996) Theory and Practice of Writing: An Applied Linguistic Perspective. Longman, New York.

[5] Liu, J. and Hansen, J. (2002) Peer Response in Second Language Writing Classrooms. University of Michigan Press, Ann Arbor. http://dx.doi.org/10.3998/mpub.8952

[6] Marjo, Z., Dominique, S. and Jeroen, M. (2010) Effective Peer Assessment Processes: Research Findings and Future Directions. Learning and Instruction, 20, 270-279. http://dx.doi.org/10.1016/j.learninstruc.2009.08.004

[7] Tsui, A.B.M. and Ng, M. (2000) Does Secondary L2 Writers Benefit from Peer Comments? Journal of Second Language Writing, 9, 147-170. http://dx.doi.org/10.1016/S1060-3743(00)00022-9

[8] Van den Berg, I., Admiraal, W. and Pilot, A. (2006) Design Principles and Outcomes of Peer Assessment in Higher Education. Studies in Higher Education, 31, 341-356. http://dx.doi.org/10.1080/03075070600680836

[9] Mo, J.H. (2005) An Exploratory Study of Conducting Peer Review among Chinese College Students. CELEA Journal, 28, 43-48.

[10] Yang, M., Richard, B. and Yu, Z. (2006) A Comparative Study of Peer and Teacher Feedback in a Chinese EFL Writing Class. Journal of Second Language Writing, 15, 179-200. http://dx.doi.org/10.1016/j.jslw.2006.09.004

[11] Nelson, G. and Carson, J. (2006) Cultural Issues in Peer Response: Revisiting "culture". In: Hyland, K. and Hyland, F., Eds., Feedback in Second Language Writing. Contexts and Issues, Cambridge University Press, New York, 42-59.

http://dx.doi.org/10.1017/cbo9781139524742.005

[12] Zhu, W. (2001) Interaction and Feedback in Mixed Peer Response Groups. Journal of Second Language Writing, 10, 251-276. http://dx.doi.org/10.1016/S1060-3743(01)00043-1

[13] Hansen, J.G. and Liu, J. (2005) Guiding Principles for Effective Peer Response. ELT Journal, 59, 31-38. http://dx.doi.org/10.1093/elt/cci004

[14] Lin, G.H.C. and Chien, P.S.C. (2009) An Investigation into Effectiveness of Peer Feedback. Journal of Applied Foreign Languages Fortune Institute of Technology, 3, 79-87.

[15] Li, L., Liu, X. and Steckelberg, A.L. (2010) Assessor or Assesse: How Student Learning Improves by Giving and Receiving Peer Feedback. British Journal of Educational Technology, 41, 525-536. http://dx.doi.org/10.1111/j.1467-8535.2009.00968.x

[16] Topping, K. (2000) Peer Assisted Learning: A Practical Guide for Teachers and Parents. New York, Cassell, London.

[17] Topping, K.J. and Ehly, S.W. (2001) Peer Assisted Learning: A Framework for Consultation. Journal of Educational and Psychological Consultation, 12, 113-132. http://dx.doi.org/10.1207/S1532768XJEPC1202_03 
[18] Xiao, Y. and Lucking, R. (2008) The Impact of Two Types of Peer Assessment on Students' Performance and Satisfaction within a Wiki Environment. Internet and Higher Education, 11, 186-193. http://dx.doi.org/10.1016/j.iheduc.2008.06.005

[19] Linn, M.C. and Slotta, J.D. (2000) WISE Science. Educational Leadership, 58, 29-32.

[20] Hovardas, T., Tsivitanidou, O.E. and Zacharia, Z.C. (2014) Peer versus Expert Feedback: An Investigation of the Quality of Peer Feedback among Secondary School Students. Computers and Education, 71, 133-152. http://dx.doi.org/10.1016/j.compedu.2013.09.019

[21] Black, P. and Wiliam, D. (2004) The Formative Purpose: Assessment Must First Promote Learning. Yearbook of the National Society for the Study of Education, 103, 20-50. http://dx.doi.org/10.1111/j.1744-7984.2004.tb00047.x

[22] Bloxham, S. and West, A. (2004) Understanding the Rules of the Game: Marking Peer Assessment as a Medium for Developing Students' Conceptions of Assessment. Assessment and Evaluation in Higher Education, 29, 721-733.

http://dx.doi.org/10.1080/0260293042000227254

[23] Carson, J. and Nelson, G. (1996) Chinese Students' Perception of ESL Peer Response Group Interaction. Journal of Second Language Writing, 5, 1-19. http://dx.doi.org/10.1016/S1060-3743(96)90012-0

[24] Hu, G. and Lam, S.T.E. (2010) Issues of Cultural Appropriateness and Pedagogical Efficacy: Exploring Peer Review in a Second Language Writing Class. Instructional Science, 38, 371 394. http://dx.doi.org/10.1007/s11251-008-9086-1

[25] Hyland, F. (2000) ESL Writers and Feedback: Giving More Autonomy to Students. Language Teaching Research, 4, 33-54. http://dx.doi.org/10.1177/136216880000400103

[26] Coté, R.A. (2014) Peer Feedback in Anonymous Peer Review in an EFL Writing Class in Spain. GIST Education and Learning Research Journal, 9, 67-87. 


\section{Appendix}

\section{Survey Sheet of Peer Feedback}

Major Age

You are a non-English -majored graduate in Yangtze University. Please answer the following questions based on your perceptions and feelings in learning writing during the past sixteen weeks. In order to ensure the confidentiality of this study, your name both in English and Chinese will be done anonymously. All of the information you gave me will be treated as completely confidential and it will not be possible for people to recognize the information you gave me when I report the results of this study.

Please give answers honestly and freely to all of the 10 questions.

When answering the questions, please fill in the following number 1. 2. 3. according to your true perceptions in learning writing through peer feedback.

1. Strongly Agree

2. Agree

\section{Not Agree}

Q1. ( ) I usually feel that my teachers' corrections for my paper influence my emotion and motivation in learning writing. I feel not confident and am nervous after reading my teachers' negative comments.

Q2. ( ) I feel more relax to read my classmate's feedback for my writings.

Q3. ( ) I prefer peer feedback to teacher's feedback.

Q4. ( ) I feel that peer feedback makes me learn more in a relaxing way.

Q5. ( ) Through cooperation and cognitive interaction with my peers, I am able to write more confidently and more supportively.

Q6. ( ) Through exchanging ideas and knowing my peer's writing proficiency, I feel much more comfortable in the writing class.

Q7. ( ) Social interaction through writing and peer feedback, provided me more inspiration (ideas) and motivations in writing.

Q8. ( ) Generally speaking, sixteen weeks, I feel that I have improved my writing skills because of the peer feedback activity in my Advanced (Writing III) English Writing course.

Q9. ( ) Hopefully, my essay and thesis can be revised and proofread by my classmates again because I can learn more.

Q10. ( ) I think peer feedback pedagogy should be applied in English classes if I will work as an English teacher in my future career. 
Submit or recommend next manuscript to SCIRP and we will provide best service for you:

Accepting pre-submission inquiries through Email, Facebook, LinkedIn, Twitter, etc. A wide selection of journals (inclusive of 9 subjects, more than 200 journals)

Providing 24-hour high-quality service

User-friendly online submission system

Fair and swift peer-review system

Efficient typesetting and proofreading procedure

Display of the result of downloads and visits, as well as the number of cited articles

Maximum dissemination of your research work

Submit your manuscript at: http://papersubmission.scirp.org/

Or contact jss@scirp.org 